\title{
Performances and Egg Quality of Laying Ducks Fed Diets Containing Cassava (Manihot esculenta Crantz) Leaf Meal and Golden Snail (Pomacea canaliculata)
}

\author{
Sumiati* , A. Darmawan, \& W. Hermana \\ Department of Nutrition and Feed Technology, Faculty of Animal Science, IPB University (Bogor Agricultural University) \\ Jalan Agatis, Kampus IPB Dramaga Bogor 16680, Indonesia \\ *Corresponding author: y_sumiati@yahoo.com \\ (Received 02-02-2020; Revised 04-05-2020; Accepted 05-05-2020)
}

\begin{abstract}
The objective of this study was to evaluate the effect of feeding cassava leaf meal and golden snail on performances, chemical, and physical qualities of local duck egg. The experiment used 180 Pajajaran laying ducks of 20 weeks of age and was offered dietary treatments up to 26 weeks of age. The experiment was conducted in a completely randomized design with a $3 \times 2$ factorial arrangement. The first factor was the treatment of cassava leaf meal consisted of 3 levels, i.e., $0 \%, 5 \%$, and $10 \%$. The second factor was the treatment of golden snail consisted of 2 levels, i.e., $0 \%$ and $10 \%$. Each experimental unit used three replicates and each replicate consisted of ten ducks. The results showed that there was no interaction effect of cassava leaf meal and golden snail treatments on laying duck performances and egg qualities. There were significant effects of cassava leaf meal and golden snail treatments $(\mathrm{p}<0.05)$ on egg production, feed intake, egg mass, egg index, and egg yolk color. However, egg weight, feed conversion ratio, yolk fat, yolk cholesterol, and yolk TBARS values, albumen weight, eggshell weight, shell thickness, and Haugh unit values were not affected $(p>0.05)$ by treatments of cassava leave meal and golden snail. The utilization of $10 \%$ cassava leaf meal in the diet significantly improved egg production, feed intake, egg mass, and yolk color $(\mathrm{p}<0.05)$. The lowest egg index was found in the eggs produced by ducks fed diet containing $5 \%$ cassava leaf meal, but it is still within the normal range. Ducks fed a diet containing $5 \%$ golden snail significantly had higher feed intake, egg mass, percentage of albumen, and yolk color. It was concluded that there was no interaction effect of cassava leaf meal and golden snail treatments on laying duck performances and egg qualities. A diet containing $10 \%$ cassava leaf meal or a diet containing $5 \%$ golden snail had the greatest effects on the performance and physical quality of egg without affecting the chemical quality of the egg.
\end{abstract}

Keywords: cassava leaf meal; laying ducks; golden snail; performances; egg quality

\section{INTRODUCTION}

Most laying ducks in Indonesia are raised in a traditional system with low productivity because of limited availability and quality of diet (Widiyaningrum et al., 2016). In addition, duck eggs also contain as much as $450 \mathrm{mg}$ of cholesterol per $50 \mathrm{~g}$ of duck egg (Chaiyasit et al., 2019). This high cholesterol content causes consumers to avoid duck egg consumption based on the belief that it raises blood cholesterol.

Dietary of cassava leaf meal (Manihot esculenta Crantz) and golden snail (Pomacea canaliculata) as local ingredients have a great potential to be used to improve diet quality of laying duck, laying duck performances, and egg qualities as well as to decrease egg cholesterol content. The great quality of diet will be achieved through the use of high quality ingredients with high protein and other active compounds contents. According to Oresegun et al. (2016), cassava leaf contains $298.00 \mu \mathrm{g} / \mathrm{g}$ to $816.92 \mu \mathrm{g} / \mathrm{g}$ beta carotene. Beta carotene is one of carotenoid with a yellow-orange pigment which is more common in the plant's leaves (Çalışlar,
2019) and it is closely related to the color of egg yolk (Bovšková et al., 2014). Beta carotene has an important role in reducing free radicals (Fiedor \& Burda, 2014) and the formation of egg follicles (Palupi et al,. 2018). In this study, beta carotene in cassava leaf meal as a natural antioxidant is expected to protect fatty acids from oxidation, which is indicated by the decreased Thiobarbituric Acid Reactive Substances (TBARS) levels (mg MDA/ $\mathrm{kg}$ ). According to Dauqan et al. (2013), malondialdehyde (MDA) is one of the markers for final products of polyunsaturated fatty acids peroxidation. Moreover, cassava leaf meal also contains high protein that can increase egg production. Cassava leaf meal contains $86.25 \%$ of dry matter, $25.81-39.90 \%$ of crude protein, and $16.28 \%$ of crude fiber (Nnaji et al., 2010; Ukanwoko \& Ukandu, 2011; Zanu \& Avukpor, 2013). However, it contains low sulfur amino acids, such as methionine and tryptophan (Adeyemi et al., 2012). Cassava leaf meal can be combined with golden snail to increase the protein quality and fatty acids in the diet. Golden snail is rice pests, which is difficult to eradicate because it can reproduce rapidly and survive in the dry land for the long term. 
Golden snails contain high unsaturated fatty acids such as oleic acid $(20.37 \%)$, linoleic acid $(20.26 \%)$, linolenic acid $(12.83 \%)$ (Subhan et al., 2010), and crude protein (48.5\%), whereas the proportion of essential amino acids is $39.7 \%$ (Ghosh et al., 2017). The combination of cassava leaf meal and the golden snail is expected to provide a good quality protein, beta carotene, and unsaturated fatty acid of diet to increase egg production performances and egg qualities. This study aimed to evaluate the effect of cassava leaf meal combined with the golden snail on performances as well as the chemical and physical qualities of egg.

\section{MATERIALS AND METHODS}

\section{Animal and Dietary Treatment}

The experiment used 180 Pajajaran laying ducks of 20 weeks of age and was offered dietary treatments up to 26 weeks of age. The experiment was conducted in a completely randomized design with a $3 \times 2$ factorial arrangement. The first factor was cassava leaf meal treatment consisted of 3 levels, i.e., $0 \%, 5 \%$, and $10 \%$. The second factor was golden snail treatment consisted of 2 levels, i.e., $0 \%$ and 5\%. Each experimental unit was replicated 3 times and each replicate consisted of ten lying ducks. The ducks were allocated randomly in a floor pen with $1 \mathrm{~cm} \times 2 \mathrm{~cm} \times 1 \mathrm{~cm}$ of cages. The diet and drinking water were provided ad libitum.

The diet ingredients used were corn, rice bran, soybean meal, cassava leaf meal, fish meal, golden snail, fish oil, $\mathrm{CaCO} 3, \mathrm{NaCl}$, premix, and DL-Methionine (Table 1). The nutritional requirement of laying duck was arranged based on isocaloric and isoprotein that contains a minimum of $2,850 \mathrm{kcal} / \mathrm{kg}$ of metabolizable energy and $16 \%$ of protein (Lesson \& Summers, 2005).

\section{Variables and Sampling}

The variables measured were duck performances, physical quality of the egg, and chemical quality of the egg. The performance variables measured included feed intake (g/bird/day), feed conversion ratio, egg mass (g/ bird/day), egg weight (g/egg), and egg quality. Egg weight and egg production were recorded daily. The physical quality variables measured included haugh unit, egg index, percentage of eggshell weight, eggshell thickness, percentage of yolk weight, percentage of albumen weight, and yolk color. The variables were taken from three eggs from each replicate at $2^{\text {nd }}, 3^{\text {rd }}, 4^{\text {th }}, 5^{\text {th }}$, and $6^{\text {th }}$ of the week. Egg weight, yolk weight, eggshell weight, and albumen weight were measured using an electronic digital balance. The eggshell thickness and albumen thickness was measured by a digital micrometer. The eggshell index was calculated as the ratio of the egg width to the egg length multiplied by $100 \%$. The yolk color was measured using the Roche color fan. The Haugh unit was calculated using the Haugh formula (Haugh, 1937).

$$
\text { Haugh Unit }=100 \log \left(\mathrm{H}-1.7 \mathrm{~W}^{0.37}+7.57\right)
$$

where $\mathrm{H}$ was Albumen thickness $(\mathrm{mm})$ and $\mathrm{W}$ was weight of the entire egg $(\mathrm{g})$.

The variables of egg chemical quality measured included yolk cholesterol, yolk lipid, and Thiobarbituric

Table 1. Ingredients and nutrient content of the treatment diet (as fed)

\begin{tabular}{|c|c|c|c|c|c|c|}
\hline \multirow{2}{*}{ Ingredients (\%) } & \multicolumn{6}{|c|}{ Treatments } \\
\hline & R0 & R1 & R2 & R3 & R4 & R5 \\
\hline Corn & 54.20 & 52.00 & 52.30 & 50.00 & 50.50 & 48.00 \\
\hline Rice bran & 9.80 & 13.20 & 8.70 & 12.00 & 7.50 & 11.00 \\
\hline Soybean & 18.60 & 13.00 & 16.80 & 11.40 & 15.00 & 10.20 \\
\hline Cassava leaf meal & 0.00 & 0.00 & 5.00 & 5.00 & 10.00 & 10.00 \\
\hline Golden snail & 0.00 & 5.00 & 0.00 & 5.00 & 0.00 & 5.00 \\
\hline Fish meal & 7.00 & 7.00 & 7.00 & 7.00 & 7.00 & 6.50 \\
\hline Fish oil & 3.00 & 3.00 & 3.00 & 3.00 & 3.00 & 3.00 \\
\hline $\mathrm{CaCO}_{3}$ & 6.60 & 6.00 & 6.40 & 5.80 & 6.20 & 5.50 \\
\hline $\mathrm{NaCl}$ & 0.20 & 0.20 & 0.20 & 0.20 & 0.20 & 0.20 \\
\hline Premix & 0.50 & 0.50 & 0.50 & 0.50 & 0.50 & 0.50 \\
\hline DL-Methionine & 0.10 & 0.10 & 0.10 & 0.10 & 0.10 & 0.10 \\
\hline Total & 100.00 & 100.00 & 100.00 & 100.00 & 100.00 & 100.00 \\
\hline \multicolumn{7}{|l|}{ Nutrient content (\%) } \\
\hline Dry matter & 88.08 & 88.34 & 86.17 & 87.25 & 88.95 & 89.32 \\
\hline Crude protein & 18.01 & 18.08 & 18.04 & 18.17 & 18.02 & 18.09 \\
\hline Crude fiber & 7.36 & 5.43 & 4.05 & 6.51 & 7.57 & 6.25 \\
\hline Crude fat & $5 . .85$ & 4.44 & 0.78 & 1.31 & 3.00 & 4.71 \\
\hline Calcium & 2.10 & 2.38 & 2.56 & 2.94 & 3.28 & 3.80 \\
\hline Phosphorus & 0.75 & 0.77 & 0.80 & 0.82 & 0.82 & 0.89 \\
\hline Metabolizable energy (kcal/kg) & 2851.44 & 2851.78 & 2851.3 & 2852.98 & 2851.45 & 2851.18 \\
\hline
\end{tabular}

Note: $\mathrm{R} 0=0 \%$ of cassava leaf meal and $0 \%$ golden snail; R $1=0 \%$ of cassava leaf meal and $5 \%$ of golden snail; R $2=5 \%$ of cassava leaf meal and $0 \%$ of golden snail; R3 $=5 \%$ of cassava leaf meal and $5 \%$ of golden snail; R4=10\% of cassava leaf meal and $0 \%$ of golden snail; R5= $10 \%$ of cassava leaf meal and $5 \%$ of golden snail. 
Acid Reactive Substances (TBARS) value. Yolk cholesterol was determined at the end of the study by using three eggs for each replicate. These sample eggs were taken randomly and analyzed using the Liebermann Burchard method. Egg yolk lipid peroxidation value was determined using Thiobarbituric Acid Reactive Substances by the method of Rice-Evans \& Anthony (1991). The absorbance was read using a spectrophotometer (Hitachi U-2001, Japan).

\section{Statistical Analysis}

The study used a completely randomized design with a $3 \times 2$ factorial assignment with three replicates and each replication used 10 laying ducks. The data were subjected to analysis of variance (ANOVA) on main and interaction effects. When a significant effect of treatment was found, Duncan's Multiple Range Test was used to determine the significant difference among mean values. Analysis of variance was performed using SPSS vr.21.0 program.

\section{RESULTS}

No interaction effect of the usages of cassava leaf meal and golden snail was found on laying duck performances and egg qualities (Table 2). There were significant effects $(\mathrm{p}<0.05)$ of cassava leaf meal and golden snail treatments on egg production, feed intake, egg mass, egg index, and egg yolk color. The treatments of cassava leaf meal and golden snail did not give a significant effect on egg weight, feed conversion ratio, yolk fat, cholesterol, TBARS values, albumen weight, eggshell weight, shell thickness, and Haugh unit value. The best egg production $(p<0.05)$ was found in the ducks fed a diet containing 10\% cassava leaf meal $(67.27 \%)$ compared to ducks fed a diet containing 5\% cassava leaf meal $(63.30 \%)$ and $0 \%$ cassava leaf meal $(64.36 \%)$. The highest feed intake was found $(\mathrm{p}<0.05)$ in ducks fed a diet containing $10 \%$ cassava leaf meal
(184.55 g/day/bird) compared to ducks fed a diet without cassava leaf meal (174.46 g/day/bird). In addition, egg mass produced by duck fed diet containing $10 \%$ cassava leaf meal (44.22 g/day/bird) was higher than those produced by ducks fed a diet containing 5\% cassava leaf meal (41.93 g/day/bird) which was statistically similar to the treatment without cassava leaf meal. Ducks fed a diet containing $5 \%$ golden snail had better $(p<0.05)$ feed intake (182.52 g/day/bird) than those fed diets without golden snail (173.54 g/day/bird). The use of $5 \%$ golden snail in the diet also increased $(p<0.05)$ egg mass compared to treatment without golden snail (Table 2).

The effects of cassava leaf meal and golden snail dietary on chemical and physical qualities of the egg are shown in Table 3 and Table 4 . The lowest egg index $(\mathrm{p}<0.05)$ was found in ducks fed a diet containing $5 \%$ cassava leaf meal $(79.07 \%)$ compared to those fed diet containing $10 \%$ cassava leaf meal (79.93\%) and diet without cassava leaf meal $(82.75 \%)$, but it is still within the normal range. Yolk color in eggs produced by ducks fed a diet containing $5 \%$ or $10 \%$ cassava leaf meal was higher $(\mathrm{p}<0.05)$ than those produced by ducks fed a diet without cassava leaf meal. A diet containing $5 \%$ golden snail significantly $(\mathrm{p}<0.05)$ increased the percentage of albumen compared to diet without golden snail. Ducks fed a diet containing 5\% golden snail also very significantly $(p<0.01)$ had higher egg yolk color compared to ducks fed a diet without golden snail.

\section{DISCUSSION}

\section{Performances of Laying Duck}

The previous studies had reported that cassava leaf meal and the golden snail could be fed to laying duck and broiler chicken without negative effects on performances. Inclusion of $10 \%$ cassava leaf meal in the diet of laying hens (Zanu \& Avukpor, 2013), 20\% cassava leaf meal in broiler diets (Abu et al., 2015) did not result in any adverse effects on performances. The golden apple

Table 2. Performance of laying ducks at 26 weeks of age

\begin{tabular}{|c|c|c|c|c|c|}
\hline \multirow{2}{*}{ Variables } & \multirow{2}{*}{ Golden snail (\%) } & \multicolumn{4}{|c|}{ Cassava leaf meal (\%) } \\
\hline & & 0 & 5 & 10 & Average \\
\hline \multirow[t]{3}{*}{ Egg production (\%) } & 0 & $62.16 \pm 1.38$ & $63.77 \pm 3.08$ & $66.28 \pm 0.85$ & $64.07 \pm 2.51$ \\
\hline & 5 & $66.56 \pm 2.26$ & $62.84 \pm 3.25$ & $68.26 \pm 1.83$ & $65.88 \pm 3.24$ \\
\hline & Average & $64.36 \pm 2.93^{\mathrm{a}}$ & $63.30 \pm 2.88^{\mathrm{a}}$ & $67.27 \pm 1.68^{\mathrm{b}}$ & $64.97 \pm 2.96$ \\
\hline \multirow[t]{3}{*}{ Egg weight (g/egg) } & 0 & $64.66 \pm 1.67$ & $66.11 \pm 1.95$ & $65.93 \pm 2.50$ & $65.57 \pm 1.92$ \\
\hline & 5 & $66.53 \pm 2.31$ & $66.45 \pm 0.85$ & $65.50 \pm 2.35$ & $66.20 \pm 1.78$ \\
\hline & Average & $65.60 \pm 2.07$ & $66.28 \pm 1.36$ & $65.71 \pm 2.18$ & $65.86 \pm 1.82$ \\
\hline \multirow[t]{3}{*}{ Feed intake (g/day/bird) } & 0 & $170.18 \pm 8.38$ & $164.63 \pm 6.01$ & $185.81 \pm 11.45$ & $173.54 \pm 12.24^{\mathrm{a}}$ \\
\hline & 5 & $178.73 \pm 9.23$ & $185.52 \pm 2.99$ & $183.30 \pm 3.05$ & $182.52 \pm 5.90^{\mathrm{b}}$ \\
\hline & Average & $174.46 \pm 9.17^{\mathrm{a}}$ & $175.07 \pm 12.20^{\mathrm{ab}}$ & $184.55 \pm 7.62^{\mathrm{b}}$ & $178.03 \pm 10.41$ \\
\hline \multirow[t]{3}{*}{ Egg mass (g/day/bird) } & 0 & $40.18 \pm 0.24$ & $42.12 \pm 0.97$ & $43.70 \pm 1.86$ & $41.99 \pm 1.86^{\mathrm{a}}$ \\
\hline & 5 & $44.25 \pm 0.46$ & $41.75 \pm 1.90$ & $44.74 \pm 2.82$ & $43.57 \pm 2.21^{b}$ \\
\hline & Average & $42.21 \pm 2.25^{\mathrm{ab}}$ & $41.93 \pm 1.36^{\mathrm{a}}$ & $44.22 \pm 2.21^{\mathrm{b}}$ & $42.27 \pm 2.13$ \\
\hline \multirow[t]{3}{*}{ Feed conversion ratio } & 0 & $4.24 \pm 0.23$ & $3.91 \pm 0.09$ & $4.25 \pm 0.27$ & $4.13 \pm 0.25$ \\
\hline & 5 & $4.04 \pm 0.17$ & $4.45 \pm 0.26$ & $4.11 \pm 0.30$ & $4.20 \pm 0.29$ \\
\hline & Average & $4.14 \pm 0.21$ & $4.18 \pm 0.34$ & $4.18 \pm 0.27$ & $4.17 \pm 0.26$ \\
\hline
\end{tabular}

Note: Means in the same row or column on each variable with different superscripts differ significantly $(p<0.05)$. 
Table 3. Fat, cholesterol, and thiobarbituric acid reactive substances (TBARS) value of egg yolk

\begin{tabular}{lccccc}
\hline \multirow{2}{*}{ Variables } & \multirow{2}{*}{ Golden snail (\%) } & \multicolumn{4}{c}{ Cassava leaf meal (\%) } \\
\cline { 3 - 6 } Fat $(\%)$ & 0 & $31.88 \pm 0.44$ & $30.86 \pm 1.11$ & $29.61 \pm 2.71$ & $30.78 \pm 1.77$ \\
& 5 & $30.54 \pm 1.92$ & $30.67 \pm 3.17$ & $31.12 \pm 0.63$ & $30.78 \pm 1.89$ \\
& Average & $31.21 \pm 1.44$ & $30.76 \pm 2.13$ & $30.36 \pm 1.94$ & $30.78 \pm 1.78$ \\
Cholesterol $(\mathrm{mg} / \mathrm{g})$ & 0 & $2.04 \pm 0.56$ & $1.47 \pm 0.48$ & $1.13 \pm 0.01$ & $1.55 \pm 0.54$ \\
& 5 & $1.56 \pm 0.55$ & $1.62 \pm 0.39$ & $1.43 \pm 0.29$ & $1.54 \pm 0.37$ \\
& Average & $1.80 \pm 0.56$ & $1.55 \pm 0.40$ & $1.28 \pm 0.24$ & $1.54 \pm 0.45$ \\
TBARS $(\mu \mathrm{gMDA} / \mathrm{g})$ & 0 & $10.36 \pm 2.23$ & $8.97 \pm 5.35$ & $6.26 \pm 2.45$ & $8.53 \pm 3.62$ \\
& 5 & $8.23 \pm 2.22$ & $9.90 \pm 3.50$ & $9.07 \pm 2.29$ & $9.07 \pm 2.48$ \\
& Average & $9.30 \pm 2.31$ & $9.44 \pm 4.08$ & $7.67 \pm 2.62$ & $8.80 \pm 3.03$ \\
\hline
\end{tabular}

Table 4. Physical egg quality of laying duck

\begin{tabular}{|c|c|c|c|c|}
\hline \multirow{2}{*}{ Variables } & \multirow{2}{*}{ Cassava leaf meal (\%) } & \multicolumn{2}{|c|}{ Golden snail (\%) } & \multirow{2}{*}{ Average } \\
\hline & & 0 & 5 & \\
\hline \multirow{3}{*}{ Egg index (\%) } & 0 & $82.61 \pm 3.12$ & $82.89 \pm 1.51$ & $82.75 \pm 2.20^{\mathrm{a}}$ \\
\hline & 5 & $80.17 \pm 1.94$ & $77.98 \pm 1.25$ & $79.07 \pm 1.89^{\mathrm{b}}$ \\
\hline & 10 & $80.14 \pm 1.30$ & $79.72 \pm 1.90$ & $79.93 \pm 1.47^{\mathrm{ab}}$ \\
\hline \multirow{3}{*}{ Albumen weight (\%) } & Average & $80.97 \pm 2.30$ & $80.20 \pm 2.55$ & $80.58 \pm 2.39$ \\
\hline & 0 & $50.91 \pm 2.85$ & $54.40 \pm 2.09$ & $52.46 \pm 2.89$ \\
\hline & 5 & $53.40 \pm 4.69$ & $48.05 \pm 2.95$ & $50.73 \pm 2.99$ \\
\hline \multirow{5}{*}{ Eggshell weight (\%) } & 10 & $48.93 \pm 5.47$ & $53.71 \pm 3.76$ & $52.24 \pm 3.56$ \\
\hline & Average & $51.08 \pm 2.38^{a}$ & $52.06 \pm 4.14^{\mathrm{b}}$ & $51.37 \pm 3.25$ \\
\hline & 0 & $12.33 \pm 0.39$ & $12.14 \pm 0.82$ & $12.27 \pm 0.56$ \\
\hline & 5 & $11.99 \pm 0.16$ & $12.12 \pm 0.30$ & $12.08 \pm 0.22$ \\
\hline & 10 & $12.28 \pm 0.73$ & $12.92 \pm 1.54$ & $12.83 \pm 1.04$ \\
\hline \multirow{4}{*}{ Shell thickness (mm) } & Average & $12.20 \pm 0.43$ & $12.39 \pm 0.95$ & $12.39 \pm 0.73$ \\
\hline & 0 & $0.39 \pm 0.03$ & $0.39 \pm 0.02$ & $0.39 \pm 0.02$ \\
\hline & 5 & $0.37 \pm 0.02$ & $0.38 \pm 0.04$ & $0.38 \pm 0.03$ \\
\hline & 10 & $0.42 \pm 0.01$ & $0.44 \pm 0.02$ & $0.44 \pm 0.02$ \\
\hline \multirow{3}{*}{ Haugh unit } & Average & $0.39 \pm 0.03$ & $0.40 \pm 0.04$ & $0.40 \pm 0.03$ \\
\hline & 0 & $91.99 \pm 2.74$ & $91.38 \pm 7.23$ & $90.73 \pm 4.18$ \\
\hline & 5 & $91.38 \pm 7.23$ & $91.70 \pm 2.89$ & $90.11 \pm 3.74$ \\
\hline \multirow{6}{*}{ Yolk color score } & 10 & $90.00 \pm 1.25$ & $93.53 \pm 4.26$ & $92.81 \pm 2.76$ \\
\hline & Average & $91.12 \pm 3.31$ & $92.21 \pm 3.97$ & $91.22 \pm 3.59$ \\
\hline & 0 & $5.56 \pm 1.07$ & $7.44 \pm 0.51$ & $6: 50 \pm 1.34^{\mathrm{a}}$ \\
\hline & 5 & $6.78 \pm 0.38$ & $8.89 \pm 0.19$ & $7.89 \pm 1.06^{\mathrm{b}}$ \\
\hline & 10 & $7.78 \pm 0.51$ & $7.89 \pm 0.19$ & $7.89 \pm 0.33^{b}$ \\
\hline & Average & $6.70 \pm 1.20^{\mathrm{A}}$ & $8.07 \pm 0.66^{\mathrm{B}}$ & $7.41 \pm 1.18$ \\
\hline
\end{tabular}

Note: Means in the same row or column on each variable with different lowercase superscripts differ significantly ( $\mathrm{p}<0.05$ ). Means in the same row with different uppercase superscripts differ significantly $(\mathrm{p}<0.01)$.

snail was reported to be able to improve egg yolk color (Syaharuddin et al., 2019). Galon et al. (2017) reported that a diet containing cassava leaf meal improved the egg production.

In the present study, the use of $10 \%$ cassava leaf meal improved egg production and feed intake. Diet supplemented with 5\% golden snail also increased feed intake and egg mass. This study resulted in a better egg weight $(65.86 \mathrm{~g} / \mathrm{egg})$ than reported by Darmawan et al. (2013). This effect was due to the highest feed intake in diet supplemented with cassava leaf meal (184.6 g/bird) so that it led to an adequate nutritional intake for egg formation. According to Olarotimi \& Adu (2017), inad- equacies in nutrients supply will lead to a decrease in egg production as well as a decline in the growth performance of broiler. Cassava leaves contained high crude protein, minerals (zinc, iron, magnesium, and calcium), vitamins such as riboflavin, niacin, thiamin, vitamin A (Ukanwoko \& Ukandu, 2011; Zanu \& Avukpor, 2013), and $298.00 \mu \mathrm{g} / \mathrm{g}$ to $816.92 \mu \mathrm{g} / \mathrm{g}$ beta carotene (Oresegun et al., 2016) that were needed for improving the egg production. According to Viana et al. (2017), the protein in the diet is important for the yolk and albumen synthesis and formation. Nassiri et al. (2012) also state that methionine is the first limiting amino acid for egg weight. Also, beta carotene also increased vitamin A formation. 
Palupi et al. (2015) state that beta carotene in the rations will be converted into vitamin A that is needed in the synthesis of steroid hormones and the development of egg yolks.

\section{Chemical and Physical Quality of Egg}

Fat content, egg cholesterol, and TBARS values were not influenced by dietary of cassava leaf meal and golden snail. Egg cholesterol content was lower than that reported by Sumiati et al. (2016), who used fish oil and vitamin $\mathrm{E}$ and Zinc mineral as an antioxidant. Low cholesterol (1.28 mg/g) and TBARS value (7.67 $\mu g M D A / g)$ in eggs produced by ducks fed a diet containing $10 \%$ cassava leaf meal indicates that beta carotene in cassava leaf meal can act as an antioxidant. In the present study, beta carotene might be effectively protected unsaturated fatty acids (omega-3 and omega-6) from the oxidation. Omega- 3 fatty acids can reduce the concentration of triglyceride by inhibiting the secretion of low-density lipoprotein (LDL) cholesterol in the liver (Innes \& Calder, 2018). Carotenoids can decrease cholesterol synthesis through inhibition of the enzyme 3-hydroxy-3-methylglutaryl coenzyme A (HMG-CoA) activity (Palozza et al., 2012; Salem, 2015).

The treatment using 5\% cassava leaf meal reduced the egg index $(79.07 \%)$, but it was still within the normal range. This decreased in the egg index may be due to the increase in egg weight of eggs produced by ducks fed diet containing 5\% cassava leaf meal. According to Begli et al. (2010) and Yilmaz et al. (2011), there is a negative correlation between egg weight and shape index. According to Srigandono (1991), a normal duck egg index ranged between $63.30 \%$ to $81.70 \%$. The egg will be more round and vice versa, with the greater the index number of the egg shape (Shoimah et al., 2019). The egg shape in the oviduct is under genetic and hormonal control (Sah \& Mishra, 2018) during the formation of eggs. The treatment of $5 \%$ golden snail increased the percentage of albumen. This increased percentage of albumen was probably caused by high protein and essential amino acids content in golden snail (Subhan et al., 2010; Ghosh et al., 2017) as a protein constituent in albumen with an average amount of $8.8 \%$ to $12.15 \%$ (Quan \& Benjakul, 2018; Chaiyasit et al., 2019). According to Huang \& Lin (2011), the main proteins in duck albumen are ovalbumin $(40 \%)$, ovotransferrin $(2 \%)$, ovomucoid $(10 \%)$, lysozyme $(1.2 \%)$, and ovomucin $(3 \%)$. The average of eggshell weight ranged from $11.99 \%$ to $12.92 \%$ and eggshell thickness ranged from $0.37 \mathrm{~mm}$ to 0.44 $\mathrm{mm}$. The standard of eggshell weight was $11 \%$ to $13 \%$ (Huang \& Lin, 2011). According to Śiątkiewicz et al. (2015), Ca is the most important nutritional factor to determine the eggshell quality, and 95\% of the shell is made up of calcium carbonate. The Haugh unit score in the present study was higher than those reported by Fouad et al. (2016) and Chaiyasit et al. (2019), which were 72.20 and 66.28, respectively. USDA categorizes for haugh unit of 72 or higher is AA quality grade for a chicken egg, and there is no standard for a duck egg (Chaiyasit et al., 2019) and a high score of the haugh unit indicates fresh egg with a thick albumen (Lee et al., 2016; Chaiyasit et al., 2019).

Dietary containing 5\% cassava leaf meal significantly increased the egg yolk color score from 6.50 to 7.83 . The use of $5 \%$ golden snail also increased the egg yolk color score from 6.70 to 8.07. The increasing yolk color score was caused by carotenoids in cassava leaf meal and golden snail. Beta carotene is a yellow-orange pigment, which is closely related to egg yolk color (Hien et al., 2016). This result was in line with the result reported by Syaharuddin et al. (2019) that the golden apple snail was able to improve the egg yolk color. Galon et al. (2017) also reported that cassava leaf meal significantly increased the yolk color.

\section{CONCLUSION}

It is concluded that there was no interaction effect of cassava leaf meal and golden snail treatments on laying duck performance and egg qualities. Dietary containing $10 \%$ cassava leaf meal or $5 \%$ golden snail had the greatest effect on the performance and physical quality of egg without affecting the chemical quality of the egg.

\section{CONFLICT OF INTEREST}

We certify that there is no conflict of interest with any financial, personal, or other relationships with other people or organizations related to the material discussed in the manuscript.

\section{ACKNOWLEDGEMENT}

The authors would like to thanks The Ministry of Research, Technology and Higher Education of the Republic of Indonesia for supporting the research funding with the contract number: 011/SP2H/LT/DRPM/ VIII/2017.

\section{REFERENCES}

Abu, A. O., I. F. Olaleru, \& A. B. Omojola. 2015. Carcass characteristics and meat quality of broilers fed cassava peel and leaf meals as replacements for maize and soyabean meal. J. Agric.Vet. Sci. Ver. 8: 2319-2372. https://doi. org/10.9790/2380-08324146

Adeyemi, O. A., J. A. Adekoya, \& R. Abayomi. 2012. Performance of broiler chickens fed diets containing cassava leaf : blood meal mix as replacement for soybean meal. Rev. Cient. Agríc. 12: 212-219.

Begli, H. E., S. Zerehdaran, S. Hassani, M. A. Abbasi, \& A. R. K. Ahmadi. 2010. Heritability, genetic and phenotypic correlations of egg quality traits in Iranian Native Fowl. British. Poult. Sci. 51: 740-744. https://doi.org/10.1080/000 71668.2010.528750

Bovšková, H., K. Míková, \& Z. Panovská. 2014. Evaluation of egg yolk colour. Czech. J. Food Sci. 32: 213-217. https://doi. org $/ 10.17221 / 47 / 2013-C J F S$

Çalışlar, S. 2019. The Important of beta carotene on poultry nutrition. Selcuk. J .Agric. Food. Sci. 33: 252-259. https://doi. org/10.15316/SJAFS.2019.185

Chaiyasit, W., R. G. Brannan, D. Chareonsuk, \& W. Chanasattru. 2019. Comparison of physicochemical and functional 
properties of chicken and duck egg albumens. Braz. J. Poult. Sci. 21: 1-10. https://doi.org/10.1590/1806-9061-2017-0705

Darmawan, A., K. G. Wiryawan, \& Sumiati. 2013. Egg production and quality of magelang duck fed diets containing different ratio of omega 3 : omega 6 and organic Zn. Med. Pet. 36: 197-202. https://doi.org/10.5398/medpet.2013.36.3.197

Dauqan, E., A. Abdullah, \& H. A. Sani. 2013. Lipid peroxidation in rat liver using different vegetable oils. The Malay. J. Analytical. Sci. 17: 300-309.

Fiedor, J. \& K. Burda. 2014. Potential role of carotenoids as antioxidants in human health and disease. Nutr. 6: 466-488. https://doi.org/10.3390/nu6020466

Fouad, A. M., D. Ruan, Y. C. Lin, C. T. Zheng, H. X. Zhang, W. Chen, S. Wang, W. G. Xia, W, \& Y. Li. 2016. Effects of dietary methionine on performance, egg quality and glutathione redox system in egg-laying ducks. Brit. Poult. Sci.57: 818-823. https://doi.org/10.1080/00071668.2016.1222 603

Galon, E. M., D. Lorenzo, \& F. Claveria. 2017. Growth and egg production performance of Dekalb layers (Gallus gallus domesticus) supplemented with cassava leaf meal (Manihot esculenta Crantz). Asian J. Agric. Biol. 5: 83-87.

Ghosh, S., C. Jung, \&V. B. Meyer-Rochow. 2017. Snail as mini-livestock: nutritional potential of farmed Pomacea canaliculata (Ampullariidae). Agric. Natur. Res. 51: 504-511. https://doi.org/10.1016/j.anres.2017.12.007

Haugh, R. R. 1937. A new method for determining the quality of an egg. US Poultry Magazine. 39: 27-49.

Hien, T. Q., N. D. Hoan, T.T. Hoan, \& T. Q. Trung. 2016. Relation between carotenoids content in egg yolk and hatching egg quality according to the time laying hens are fed diet containing leaf meal. Bulgarian. J. Agric. Sci. 22 (Supple. 1): 92-98.

Huang, J. F. \& C. C. Lin. 2011. Production, Composition, and Quality of Duck Eggs. Woodhead Publishing Limited. https://doi.org/10.1533/9780857093912.4.487

Innes, J. K, \& P. C. Calder. 2018. The differential effects of eicosapentaenoic acid and docosahexaenoic acid on cardiometabolic risk factors: A systematic review. Int. J. Mol. Sci.19: 532. https://doi.org/10.3390/ijms19020532

Lee, M. H., E. J. Cho, E. S. Choi, \& S. H. Sohn. 2016. The effect of storage period and temperature on egg quality in commercial eggs. Korean. J. Poult. Sci. 43: 31-38. https:// doi.org/10.5536/kjps.2016.43.1.31

Lesson, S. \& J. D. Summers. 2005. Commercial Poultry Nutrition. $3^{\text {rd }}$ Ed. Department of Animal and Poultry Science, University of Guelph. University Books, Guleph.

Nassiri, M. H., M. K. Fard, M. J. Agah, S. J. Hosseini, \& M. T. Mirakzehi. 2012. Effect of different levels of methionine, protein and tallow on the productive performance and egg quality of laying hens in the late-phase production. Rev. Bras. de Ciencia Avic. 14: 149-158. https://doi.org/10.1590/ S1516-635X2012000200010

Nnaji, J.C., F. C. Okoye, \& V. O. Omeje. 2010. Screening of leaf meals as feed supplements in the culture of Oreochromis niloticus. Afric. J. Food. Agric. Nutr Develop. 10: 2112-2123. https://doi.org/10.4314/ajfand.v10i2.53354

Olarotimi, O. J. \& O. A. Adu. 2017. Potentials of non-conventional protein sources in poultry nutrition. Arch. de Zoot. 66: 287-299. https://doi.org/10.21071/az.v66i255.2524

Oresegun, A., O. A. Fagbenro, P. Ilona, \& E. Bernard. 2016. Nutritional and anti-nutritional composition of cassava leaf protein concentrate from six cassava varieties for use inaquafeed. Cogent Food. Agric.2: 1-6. https://doi.org/10.1 080/23311932.2016.1147323

Palozza, P., A. Catalano, R. E. Simone, M. C. Mele, \& A. Cittadini. 2012. Effect of lycopene and tomato products on cholesterol metabolism. Ann. Nutr. Met. 61: 126-134. https://doi.org/10.1159/000342077
Palupi, R., L. Abdullah, D. A. Astuti, \& Sumiati. 2015. Potential and utilization of Indigofera sp shoot leaf meal as soybean meal substitution in laying hen diets. J. Ilmu Ter. Vet.19: 210-219. https://doi.org/10.14334/jitv.v19i3.1084

Palupi, R., F. N. Lubis, R. Rismawati, I. Sudibyo, \& R. A. R. Siddiq. 2018. Effect of Indigofera zollingeriana top leaf meal supplementation as natural antioxidant source on production and quality of pegagan duck eggs. Bul. Pet. 42: 301307. https://doi.org/10.21059/buletinpeternak.v42i4.22881

Quan, T. H. \& S. Benjakul. 2018. Quality, protease inhibitor and gelling property of duck egg albumen as affected by storage conditions. J. Food Sci. Tech.55: 513-522. https:// doi.org/10.1007/s13197-017-2960-6

Rice-Evans, C. \& T. D. Anthony. 1991. Techniques in Free Radical Research. Elsevier. pp. 146-202.

Sah, N. \& B. Mishra. 2018. Regulation of egg formation in the oviduct of laying hen. World's Poult. Sci. J.74: 509-522. https://doi.org/10.1017/S0043933918000442

Salem, S. 2015. Effect of two carotenoids (Lycopene and $\beta$-Carotene) supplementation on hyperlipidemia and lipid peroxidation in experimental albino rats. J. High. Inst. Pub. Health 45: 1-7. https://doi.org/10.21608/jhiph.2015.20262

Shoimah, D., I. H. Djunaidi, \& O. Sjofjan. 2019. Quality of duck eggs maintained using a different maintenance system in the Malang Raya area. Int. Res. J. Adv. Eng. Sci. 4: 273-277.

Śiątkiewicz, S., A. Arczewska-Włosek, J. Krawczyk, M. Puchała, \& D. Józefiak. 2015. Effects on performance and eggshell quality of particle size of calcium sources in laying hens' diets with different $\mathrm{Ca}$ concentrations. Archiv. Tierzucht. 58: 301-307. https://doi.org/10.5194/aab-58-301-2015

Srigandono, B. 1991. The Science of Waterfowl. Gadjah Mada University Press, Indonesia.

Subhan, A., T. Yuwanta, H. P. S. Jafendi, \& E. S. Rohaeni. 2010. Pengaruh pemberian kombinasi sagu kukus (Metroxylon Spp) dan tepung keong mas (Pomacea Spp) sebagai pengganti jagung kuning terhadap penampilan itik jantan Alabio, Mojosari dan MA. J. Ilmu Ter. Vet. 15: 165-173.

Sumiati, A. Darmawan, \& K. G. Wiryawan. 2016. Egg quality and blood hematology of magelang laying duck fed with diets containing different ratios of omega 3 and omega 6 fatty acids and organic Zn. Int. J. Poult. Sci. 15: 448-453. https://doi.org/10.3923/ijps.2016.448.453

Syaharuddin, N., R. Rasdyanah, D. K. Sari, W. S. Monica, \& A. W. Jamaluddin. 2019. Combination effect of golden snail powder and fermented coconut cake on quality of duck eggs. J. Ind. Vet. Res. 3: 47-56. https://doi.org/10.20956/jrvi. v3i2.6627

Ukanwoko, A. I. \& C. Ukandu. 2011. Proximate composition of cassava peels ensiled with cassava, gliricidia and Leucaena leaf meals prepared under a humid environment. Continental J. Animal and Veterinary Research. 3: 36-40.

Viana, E. de F., J. H. Stringhini, F. B. de Carvalho, D. M. P.Viana, \& M. A. da Costa. 2017. Effects of crude protein levels on egg quality traits of brown layers raised in two production systems. Rev. Bras. de Zoo.46: 847-855. https:// doi.org/10.1590/S1806-92902017001100003

Widiyaningrum, P., Lisdiana, \& N. R. Utami. 2016. Egg production and hatchability of local ducks under semi intensive vs extensive managements. J. Ind. Trop. Anim. Agric. 41: 77-82. https://doi.org/10.14710/jitaa.41.2.77-82

Yilmaz, A., C. Tepeli, \& T. Çağlayan. 2011. External and internal egg quality characteristics in Japanese quails of different plumage color lines. J. Food. Agric. Env. 9: 375-379.

Zanu, H. K. \& C. M. Avukpor. 2013. Effects of enzyme (xzyme) supplementation on the performance of laying hens fed diets containing different levels of cassava (Manihot esculenta, Crantz) leaf meal. Online J. Anim. Feed Res. 3: 9-14. 